\title{
Tissue and isoform-selective activation of protein kinase $C$ in insulin-resistant obese Zucker rats - effects of feeding
}

\author{
X Qu ${ }^{1}$, J P Seale ${ }^{1}$ and R Donnelly, \\ ${ }^{1}$ Department of Pharmacology, University of Sydney, Sydney, Australia \\ ${ }^{2}$ School of Medical and Surgical Sciences, University of Nottingham, Derbyshire Royal Infirmary, Derby, UK \\ (Requests for offprints should be addressed to R Donnelly, School of Medical and Surgical Sciences, University of Nottingham, Derbyshire Royal Infirmary, \\ Derby DE1 2QY, UK)
}

\begin{abstract}
The mechanisms of insulin resistance in the obese Zucker rat have not been clearly established but increased diacylglycerol-protein kinase C (DAG-PKC) signalling has been associated with decreased glucose utilisation in states of insulin resistance and non-insulin-dependent diabetes mellitus. The purpose of this study was to characterise tissue- and isoform-selective differences in DAG-PKC signalling in insulin-sensitive tissues from obese Zucker rats, and to assess the effects of feeding on DAG-PKC pathways. Groups of male obese $(f a / f a, n=24)$ and lean $(f a /-, n=24)$ Zucker rats were studied after baseline measurements of fasting serum glucose, triglycerides, insulin and oral glucose tolerance tests. Liver, epididymal fat and soleus muscle samples were obtained from fed and overnight-fasted rats for measurements of DAG, $\mathrm{PKC}$ activity and individual PKC isoforms in cytosol and membrane fractions. Obese rats were heavier $(488 \pm 7$ vs $315 \pm 9 \mathrm{~g})$ with fasting hyperglycaemia $(10 \cdot 5 \pm 0 \cdot 8$ vs $7 \cdot 7 \pm 0 \cdot 1 \mathrm{mM})$ and hyperinsulinaemia $(7167 \pm 363$ vs $251 \pm 62 \mathrm{pM}$ ) relative to lean controls. In fasted rats, PKC
\end{abstract}

activity in the membrane fraction of liver was significantly higher in the obese group (174 \pm 16 vs $108 \pm 12 \mathrm{pmol} /$ $\mathrm{min} / \mathrm{mg}$ protein, $P<0 \cdot 05$ ) but there were no differences in muscle and fat. The fed state was associated with increased DAG levels and threefold higher PKC activity in muscle tissue of obese rats, and increased expression of the major muscle isoforms, PKC- $\theta$ and PKC-E: e.g. PKC activity in the membrane fraction of muscle from obese animals was $283 \pm 42$ (fed) vs $107 \pm 20 \mathrm{pmol} / \mathrm{min} / \mathrm{mg}$ protein (fasting) compared with $197 \pm 27$ (fed) and $154 \pm 21 \mathrm{pmol} /$ $\mathrm{min} / \mathrm{mg}$ protein (fasting) in lean rats. In conclusion, hepatic PKC activity is higher in obese rats under basal fasting conditions and feeding-induced activation of DAG-PKC signalling occurs selectively in muscle of obese $(f a / f a)$ rats due to increased DAG-mediated activation and/or synthesis of PKC- $\theta$ and PKC- $\varepsilon$. These changes in PKC are likely to exacerbate the hyperglycaemia and hypertriglyceridaemia associated with obesity-induced diabetes.

Journal of Endocrinology (1999) 162, 207-214

\section{Introduction}

There is a negative linear relationship between body mass index and whole-body insulin sensitivity (Ferrannini et al. 1997). Obese patients and especially those with a high waist-to-hip ratio are insulin resistant and develop a compensatory increase in circulating plasma insulin concentrations. Type 2 (non-insulin-dependent) diabetes mellitus (NIDDM) often supervenes when the pancreatic insulin response is either defective or insufficient to maintain normal glucose tolerance.

The insulin resistance associated with obesity and diabetes affects multiple pathways of glucose and lipid metabolism in peripheral tissues (i.e. muscle/fat) and the liver. The underlying biochemical mechanisms have not been clearly established (Moule \& Denton 1997), but most of the available evidence points to defects at or beyond the insulin receptor and in muscle tissue there is a strong link between insulin resistance and increased lipid availability (i.e. triglyceride and diglyceride levels) (Pan et al. 1997). Boneh (1995) has proposed that accumulation of lipid metabolites, via activation of protein kinases such as protein kinase C (PKC), leads to dysregulated substrate phosphorylation and cellular function. Thus, since the reversible addition of phosphate groups by intracellular kinases and phosphatases is an important mechanism for regulating cell-surface receptors and metabolising enzymes, it has been further suggested that changes in the phosphorylation state of key elements in the insulin signalling cascade may contribute to the down-regulation of insulin-mediated responses observed in obesity and other insulin-resistant states (Cortright et al. 1997).

The serine/threonine-specific protein kinase, PKC, has been particularly implicated in the pathogenesis of insulin resistance (Considine \& Caro 1993, Shmueli et al. 1993). For example, increased diacylglycerol (DAG)-mediated 
PKC activation has been associated with insulin resistance in humans and animals with diabetes (Considine et al. 1995), and there is evidence of PKC activation in models of obesity (Avignon et al. 1996), ageing (Ishizuka et al. 1993), muscle denervation (Heydrick et al. 1991) and dietary-induced insulin resistance (Donnelly et al. 1994, Schmitz-Peiffer et al. 1997). There is also evidence that hyperglycaemia-induced insulin receptor inhibition is mediated by PKC (Berti et al. 1994). The mechanisms by which PKC activation may down-regulate one or more steps involved in glucose transport and metabolism include decreased autophosphorylation and tyrosine kinase activity of the insulin receptor (Karisik et al. 1990, Kellerer et al. 1997), inactivation of glycogen synthase (Blackmore et al. 1986), inhibition of insulin-stimulated Akt1 and Akt3 activity (Barthel et al. 1998), increased insulin receptor degradation (Mosthaf et al. 1998) and increased phosphorylation of insulin receptor substrate-1 (Busch et al. 1998).

PKC represents a family of 12 isoenzymes with different biochemical characteristics, substrates and cofactor (calcium and/or phospholipid) requirements (Hug \& Sarre 1993), and the novel (group B) PKCs (nPKC- $\delta,-\varepsilon . \theta$ and $\eta)$ have been particularly implicated in insulin resistance (Donnelly et al. 1994, Kellerer et al. 1997, Schmitz-Peiffer et al. 1997). The obese Zucker rat is an excellent model of early-stage NIDDM induced by insulin resistance, overeating and overweight. The model is homozygous for the fatty $(f a)$ mutation in the leptin receptor (the same gene is mutated in the diabetes $(d b)$ mouse (Chua et al. 1996)), and the insulin resistance affects primarily muscle with failure of glucose transporter function (King et al. 1992). The purpose of this study was to characterise changes in DAG-PKC signalling in tissues from the obese Zucker rat, and to evaluate whether PKC activity and isoform distribution is influenced by feeding.

\section{Materials and Methods}

\section{Animals}

Male obese $f a / f a$ Zucker rats $(n=24)$ and lean non-obese $\mathrm{fa} /$ - controls $(n=24)$ were obtained from Monash University Animal Supplies (Victoria, Australia) at 9 weeks of age and housed under controlled conditions of temperature $\left(21^{\circ} \mathrm{C}\right)$ and lighting $(12 \mathrm{~h}$ light-darkness cycle, lights on $0600 \mathrm{~h}$ ) with free access to water and standard laboratory chow. The experimental protocol was approved by the University of Sydney Animal Care and Ethics Committee.

\section{Metabolic measurements}

Blood samples were drawn from the tail vein of unanaesthetised rats for measurements of fasting serum glucose, insulin and triglyceride (TG) concentrations. Fasting glucose levels were measured at weekly intervals until the obese Zucker rats became diabetic at approximately 13 weeks of age. Thereafter, following a 5-h fast, oral glucose tolerance tests (OGTT) were performed on groups of obese $(f a / f a)(n=24)$ and lean $(f a /-)(n=24)$ animals. Tail vein blood samples were collected at baseline and at 30 , 60, 90, 120 and $180 \mathrm{~min}$ after an oral glucose load $(2 \mathrm{~g} / \mathrm{kg})$ administered by gavage.

\section{Collection of tissue samples in fed and fasted conditions}

Two days after the OGTT, obese and lean Zucker rats were subdivided into two further groups, overnight-fasted $(n=12)$ and fed $(n=12)$ animals, prior to exsanguination at $0900 \mathrm{~h}$. Tissue samples (liver, epididymal fat pad and soleus muscle) were quickly excised following decapitation, snap-frozen in liquid $\mathrm{N}_{2}$ and stored at $-70{ }^{\circ} \mathrm{C}$ for subsequent biochemical assays of PKC activity, DAG levels and Western blotting in cytosol and membrane (particulate) fractions. Tissue samples were homogenised in a Polytron (Brinkman Instruments, Westbury, NY, USA) in $100 \mathrm{mg} / \mathrm{ml}$ buffer A (containing $20 \mathrm{mM}$ Tris$\mathrm{HCl}, \mathrm{pH} 7 \cdot 4,1 \mathrm{mM}$ EDTA, 0.25 mM EGTA, $2 \mu \mathrm{g} / \mathrm{ml}$ leupeptin, $4 \mu \mathrm{g} / \mathrm{ml}$ pepstatin, $4 \mu \mathrm{g} / \mathrm{ml}$ each of calpain I and II inhibitors, $0 \cdot 2 \mathrm{mM}$ phenylmethylsulphonyl fluoride and $0.25 \mathrm{M}$ sucrose). For subfractionation of the crude homogenate into cytosol and particulate fractions, the samples were first spun at $400 \times g$ for $15 \mathrm{~min}$. The supernatant for liver and muscle, and the infranatant below the fat cake for adipose tissue, were then ultracentrifuged at $105000 \times \boldsymbol{g}$ for $60 \mathrm{~min}$. The supernatant was removed as the cytosol fraction; the sediment (particulate fraction) was resuspended in $0.5 \mathrm{ml}$ buffer $\mathrm{A}$, then mixed with $0.5 \mathrm{ml}$ buffer B (buffer A without sucrose) containing $2 \%$ Triton X-100 and solubilised for $30 \mathrm{~s}$ in a sonic dismembrator at $4{ }^{\circ} \mathrm{C}$. An aliquot of each fraction was saved for protein quantification (Bradford 1976), and cytosol and particulate samples were then used for biochemical assays of PKC activity, DAG content and Western blotting.

\section{Protein kinase $C$ activity}

PKC activity is virtually undetectable in crude subcellular fractions but is expressed following DEAE-cellulose chromatography to remove inhibitors, phosphatases and other protein kinases. Thus, PKC activity was measured in partially purified preparations of cytosolic and particulate (membrane) fractions, as described previously (Azhar 1991, Donnelly et al. 1994). In brief, the supernatant and particulate fractions were applied to DEAE-Sephacryl columns (Pharmacia, NSW, Australia) and eluted in 3-ml fractions from the column using buffer B containing $0 \cdot 15 \mathrm{M} \mathrm{NaCl}$. Enzyme activity was assayed immediately after completion of the chromatography step by following the incorporation of $\left[{ }^{32} \mathrm{P}\right]$ from $\left[\gamma-{ }^{32} \mathrm{P}\right] \mathrm{ATP}$ into glycogen synthase (GS). The standard incubation mixture consisted of the following components in a final volume of $100 \mu$ : 
$20 \mu \mathrm{l}$ aliquots of chromatography fractions, $25 \mathrm{mM}$ PIPES$\mathrm{NaOH}(\mathrm{pH} 6 \cdot 8$ ), $10 \mathrm{mM}$ magnesium acetate, $20 \mu \mathrm{M}$ GS peptide, $5 \mathrm{mM} 2$-mercaptoethanol, $0 \cdot 1 \mathrm{mM}\left[\gamma_{-}{ }^{32} \mathrm{P}\right] \mathrm{ATP}$ (200-300 c.p.m./pmol), $1.0 \mathrm{mM} \mathrm{CaCl}, 150 \mu \mathrm{g} / \mathrm{ml}$ phosphatidylserine, and $10 \mu \mathrm{g} / \mathrm{ml}$ diolein. Basal activity was determined in the presence of $0.5 \mathrm{mM}$ EGTA (instead of $\mathrm{Ca}^{2+}$, phosphatidylserine and diolein). The reaction was initiated by the addition of $\left[\gamma-{ }^{32} \mathrm{P}\right] \mathrm{ATP}$ at $30{ }^{\circ} \mathrm{C}$ and terminated after $15 \mathrm{~min}$ by spotting $50 \mu \mathrm{l}$ of the mixture onto $2 \times 2 \mathrm{~cm}$ phosphocellulose strips (Whatman P81) which were dropped immediately into $75 \mathrm{mM}$ phosphoric acid. The strips were then washed in $75 \mathrm{mM}$ phosphoric acid, dried and counted in a scintillation counter (Beckman LS No. 3801). PKC activity was calculated by subtracting the enzyme activity observed in the presence of $0.5 \mathrm{mM}$ EGTA from that measured in the presence of phosphatidylserine, diolein and calcium. One unit of PKC activity is defined as that amount catalysing the transfer of 1 pmol $\left[{ }^{32} \mathrm{P}\right]$ phosphate from $\left[\gamma_{-}{ }^{32} \mathrm{P}\right]$ ATP to GS peptide per min at $30^{\circ} \mathrm{C}$.

\section{Western blotting}

Aliquots of the cytosol and particulate fractions were mixed with equal volumes of $2 \times$ sample-loading buffer $(4 \cdot 6 \%(\mathrm{w} / \mathrm{v})$ sodium dodecyl sulphate $(\mathrm{SDS}), 10 \%(\mathrm{v} / \mathrm{v})$ $\beta$-mercaptoethanol, $16 \%(\mathrm{w} / \mathrm{v})$ sucrose, and $0.1 \mathrm{M}$ Tris$\mathrm{HC} 1, \mathrm{pH} 6 \cdot 8$ ), heated at $95^{\circ} \mathrm{C}$ for $5 \mathrm{~min}$, and cooled to room temperature. The mixture was then centrifuged at $5000 \times g$ for $5 \mathrm{~min}$, and the supernatant subjected to sodium dodecylsulphate polyacrylamide gel electrophoresis (SDS-PAGE), as described by Laemmli (1970). For each sample, $25 \mu \mathrm{g}$ total protein were loaded onto the gel together with one lane of protein standards per gel (Bio-Rad Laboratories, Richmond, CA, USA). Following electrophoretic separation, proteins were transferred to Immobilon-P membranes (Millipore, Bedford, MA, USA) in transfer buffer containing $10 \mathrm{mM}$ CAPS (3[cyclohexylamino]-1-propane sulphonic acid) and 10\% methanol, pH 11. The membrane was then incubated for $12 \mathrm{~h}$ at $4{ }^{\circ} \mathrm{C}$ in phosphate-buffered saline-Tween (PBS-T) containing $5 \%(\mathrm{w} / \mathrm{v})$ non-fat dried milk, $\mathrm{pH} 7 \cdot 4$. After the blocking step, membranes were washed in rinsing solution (PBS-T with 1\% dried milk, pH 7.4) and then incubated overnight with an affinity-purified polyclonal antibody specific for the $\theta$ (Donnelly et al. 1994) and $\varepsilon$ (Transduction Laboratories, MA, USA) isoenzymic forms of PKC. After further washings, membranes were incubated with horseradish peroxidase-conjugated immunoglobulin G (IgG) fraction of goat antirabbit IgG, diluted 1:20 000 in PBS-T. The membranes were then washed several times in PBS-T, incubated with alkaline phosphatasestreptavidin-conjugated antirabbit IgG and developed for 60 s using a commercial enhanced chemiluminescence kit (Zymed Laboratories, San Francisco, CA, USA). Each film was exposed for $60 \mathrm{~s}$. The bands obtained from immuno- blotting were scanned by one-dimensional laser densitometry and the areas under the peaks were analysed using the Gelscan XL software package.

\section{Measurement of 1,2-diacylglycerol (DAG)}

DAG was extracted by the method of Bligh and Dyer (1959) and measured by a slightly modified version of the DAG kinase procedure of Preiss et al. (1987). Dioleoylglycerol was used for the standard curve. Briefly, after extraction the dried lipid extracts were solubilised by sonication in $20 \mu \mathrm{l}$ of a solution containing octyl- $\beta$-D glucoside $(7 \cdot 5 \%)$ and cardiolipin $(5 \mathrm{mM})$ in $1 \mathrm{mM}$ diethylenetriamine pentaacetic acid (DETAPAC). After $15 \mathrm{~min}$ incubation, $50 \mu \mathrm{l} 2 \times$ reaction buffer $(100 \mathrm{mM}$ imidazole-HC1, pH 6.6, $100 \mathrm{mM} \mathrm{NaCl}, 25 \mathrm{mM} \mathrm{MgCl}_{2}$, $2 \mathrm{mM}$ EGTA) and $10 \mu \mathrm{l} 20 \mathrm{mM}$ dithiothreitol were mixed with the solubilised lipid/octylglucoside solution and purified DAG kinase to give a final volume of $90 \mu$. The reaction was started by addition of $10 \mu \mathrm{l}\left[\gamma-{ }^{32} \mathrm{P}\right] \mathrm{ATP}$ (specific activity $5 \times 10^{5}$ c.p.m. $/ \mathrm{nmol}$ ) in $10 \mathrm{mM}$ imidazole, $1 \mathrm{mM}$ DETAPAC, pH 6.6, and allowed to proceed at $25{ }^{\circ} \mathrm{C}$ for $30 \mathrm{~min}$. The reaction was stopped by adding $3 \mathrm{ml}$ chloroform/methanol $(1: 2, \mathrm{v} / \mathrm{v})$ and $0.7 \mathrm{ml} 1 \%$ $\mathrm{HCIO}_{4}$. After addition of $1 \mathrm{ml} \mathrm{CHCl}$ and $1 \mathrm{ml} 1 \%$ perchloric acid, and brief centrifugation, the lower chloroform phase was washed and then dried under $\mathrm{N}_{2}$. The lipid film was dissolved in 5\% methanol in chloroform and $50 \mu \mathrm{l}$ spotted on to a $20 \mathrm{~cm}$ Silica Gel 60 TLC plate activated by prerunning in acetone. Samples of $\left[\gamma-{ }^{32} \mathrm{P}\right]$ phosphatidic acid made from dioleoylglycerol were also spotted onto the TLC plates as standards. The plates were then developed with chloroform:methanol:acetic acid $(65: 15: 5, \mathrm{v} / \mathrm{v})$, air dried and subjected to autoradiography. The radioactive spot corresponding to phosphatidic acid $\left(R_{f}=0.35\right)$ was scraped into a scintillation vial, mixed with $6 \mathrm{ml}$ scintillation fluid, and counted.

\section{Other assays}

Serum glucose and triglyceride levels were measured using enzymatic colorimetric methods (Trinder Glucose kit and GPO-Trinder Tryglyceride kit, Sigma, St Louis, MO, USA). Serum insulin concentrations were measured by double-antibody radioimmunoassay using rat insulin standards $(0-8 \mathrm{ng} / \mathrm{ml}$ range $)$ and a guinea pig anti-rat insulin primary antibody (Linco Research Inc., St Louis, MO, USA).

\section{Statistical analysis}

Serum glucose concentration- and insulin concentrationtime profiles for the oral glucose tolerance tests were compared by ANOVA. Measurements of fasting serum glucose, insulin and triglyceride concentrations were analysed by one factor ANOVA. All measurements are 
Table 1 Comparison of fasting serum glucose, triglyceride and insulin concentrations in obese $f_{a} / f a(n=24)$ and lean $f a /-(n=24)$ rats at 10 and 13 weeks of age. Values are means \pm S.E.M.

\begin{tabular}{|c|c|c|c|c|}
\hline & \multicolumn{2}{|l|}{10 weeks } & \multicolumn{2}{|l|}{13 weeks } \\
\hline & Lean & Obese & Lean & Obese \\
\hline \multicolumn{5}{|l|}{ Parameters } \\
\hline Body weight (g) & $266 \pm 11$ & $315 \pm 9$ & $315 \pm 9$ & $488 \pm 7^{*}$ \\
\hline Glucose $(\mathrm{mmol} / \mathrm{l})$ & $7 \cdot 1 \pm 0 \cdot 2$ & $7 \cdot 7 \pm 0 \cdot 1$ & $7 \cdot 7 \pm 0 \cdot 1$ & $10 \cdot 5 \pm 0 \cdot 81^{* *}$ \\
\hline Triglyceride (mmol/l) & $1 \cdot 57 \pm 0 \cdot 04$ & $1 \cdot 43 \pm 0.05$ & $1 \cdot 43 \pm 0.05$ & $4 \cdot 08 \pm 0 \cdot 16^{\star * \star}$ \\
\hline Insulin $(\mathrm{pmol} / \mathrm{l})$ & $208 \pm 85$ & $251 \pm 62$ & $251 \pm 62$ & $7167 \pm 363^{* * *}$ \\
\hline
\end{tabular}

expressed as means \pm standard error (S.E.M.) and statistical significance was accepted at the $5 \%$ level.

\section{Results}

\section{Metabolic characteristics of obese fa/fa Zucker rats}

Obese rats at 10 weeks of age had fasting serum glucose concentrations within the normal range but fasting triglyceride and insulin levels were significantly higher than in lean $(f a /-)$ controls. At 13 weeks, the genetically obese fa/fa Zucker rats were significantly overweight ( $488 \pm 7$ vs $315 \pm 9 \mathrm{~g}$ ) with marked hyperinsulinaemia and hypertriglyceridaemia compared with their lean counterparts (Table 1). Furthermore, by 13 weeks of age the obese rats had become diabetic (Fig. 1). Following an oral glucose tolerance test, the area-under-the-curve (AUC) of the serum glucose concentration-time profile was significantly higher in obese rats: AUC[glu] was $47 \cdot 4 \pm 13.3 \mathrm{mmol} . \mathrm{h} / 1$ in obese rats vs $25.0 \pm 1.6 \mathrm{mmol} . \mathrm{h} / \mathrm{l}$ in lean controls $(P<0 \cdot 001$, Fig. 1). The insulin response to the oral glucose stimulus was also significantly higher: AUC[insulin] was $20644 \pm 1128 \mathrm{mmol} . \mathrm{h} / \mathrm{l}$ for obese rats compared with $2392 \pm 327$ pmol.h/l for lean rats $(P<0 \cdot 001$, Fig. 1$)$.

\section{$P K C$ activity in insulin target tissues in fed and} fasted conditions

PKC activity was generally lower in the cytosol fraction compared with the membrane fraction of all three tissues (liver, soleus muscle and fat) in both obese and lean rats (Table 2). In fasted animals, PKC activity in the membrane fraction of liver was significantly higher in obese compared with lean rats but there were no significant differences in muscle and fat (Table 2).

In obese Zucker rats, feeding was associated with almost a threefold increase in PKC activity in the membrane fraction of skeletal muscle but no increase in liver or fat tissue (Table 2). In lean rats, however, PKC activity in the cytosol and membrane fractions of soleus muscle was similar in fed and fasted conditions.
$D A G$ levels and immunoblot analysis of major PKC isoforms in soleus muscle

In order to investigate the mechanism underlying the observed increase in PKC activity in the soleus muscle of obese Zucker rats under fed conditions, Western blotting was performed to evaluate the expression of the two major isoenzymic forms of $\mathrm{PKC}$ in muscle, $\mathrm{PKC}-\theta$ and $\mathrm{PKC}-\varepsilon$, both of which have been implicated in the insulin resistance of skeletal muscle (Donnelly et al. 1994, SchmitzPeiffer et al. 1997). The results show that in obese rats there is increased expression of PKC- $\theta$ and especially PKC- $\varepsilon$ in the membrane fraction of soleus muscle in the fed compared with the fasting state (Figs 2 and 3, and Table 3). Under fasted conditions, there were no differences in isoform expression in muscle between obese and lean animals.

To assess whether changes in DAG may be responsible for the increased activation of $\mathrm{PKC}$, and the increased expression of $\mathrm{nPKCs}$ in the membrane fraction associated with feeding, DAG content was measured in the cytosol and membrane fractions of soleus muscle from obese and lean rats. In the fasting state, DAG levels were significantly higher in the cytosol fraction of muscle from obese rats, but absolute levels of DAG were higher in the membrane fraction, especially in the fed state (Table 4).

\section{Discussion}

These results show that there are tissue- and isoformspecific differences in PKC signalling in obese $(f a / f a)$ compared with lean ( $f a /-)$ Zucker rats under fed and fasted conditions. Obese diabetic animals in the basal fasting state had higher PKC activity in liver but not muscle or fat. Similar 40\% increases in membrane-associated PKC were reported in liver biopsy specimens from obese patients with NIDDM (Considine et al. 1995), and in parallel experiments in rats these authors showed that the increase in liver PKC in NIDDM is not secondary to hyperglycaemia. Given that PKC activation in hepatocytes reduces insulin-stimulated glycogen and lipid synthesis (Caro et al. 

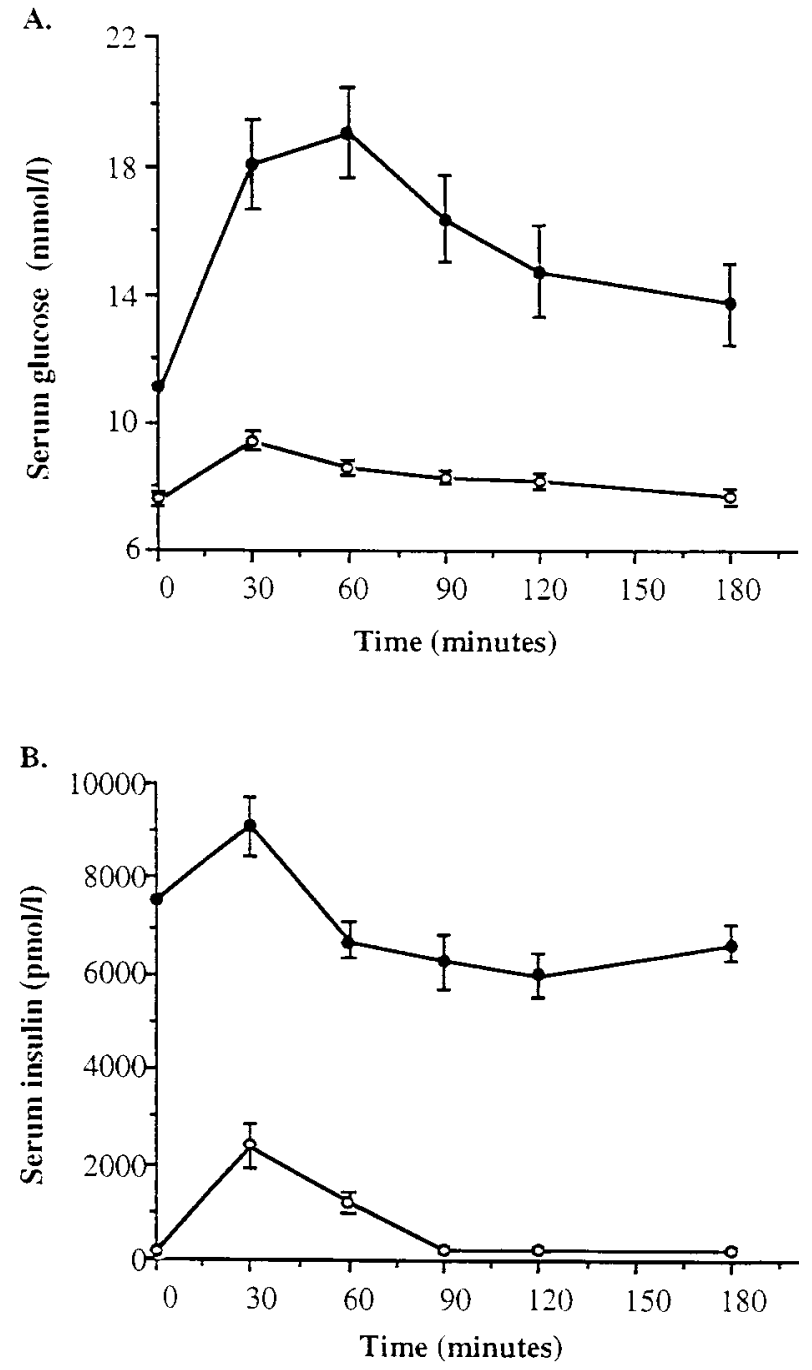

Figure 1 Serum glucose $(\mathrm{A})$ and insulin $(\mathrm{B})$ responses to an oral glucose load ( $2 \mathrm{~g} / \mathrm{kg}$ body weight) by gavage in fasted obese $(\mathrm{fa} / \mathrm{fa})(\bullet, n=12)$ and lean $\mathrm{fa} /-(\bigcirc, n=12)$ Zucker rats. Values are means \pm S.E.M.

1992), and overexpression of PKC decreases phosphatidylinositol (PI) 3-kinase activity (Chin et al. 1993), the results of the present study suggest that the increase in PKC activity in liver may be exacerbating the metabolic abnormalities of fasting hyperglycaemia and hypertriglyceridaemia observed in obese Zucker rats. It has been shown that activation of hepatic PI 3-kinase is markedly reduced in obese Zucker rats (Anai et al. 1998), via down-regulation of insulin receptor substrate (IRS)-1 and IRS-2, and this may involve PKC-mediated phosphorylation of insulin receptor substrates at the serine 612 position (De Fea \& Roth 1997).

Rats feed mainly at night, and in the obese group following an overnight feed there was a nearly threefold increase in PKC activity in the membrane fraction of red muscle. In contrast, feeding had no effect on muscle PKC activity in lean animals, and there were no changes in PKC activity in liver or fat in response to food intake. The explanation for the tissue-selective increase in PKC activity after overnight feeding is not entirely clear, and of course this study did not measure PKC activity in situ, but there was a parallel increase in DAG levels and evidence of DAG-mediated activation of the two major isoenzymic forms of PKC in skeletal muscle, PKC- $\theta$ and PKC- $\varepsilon$. There was no direct evidence of translocation, since cytosolic PKC enzyme activity was unchanged. However, PKC activation in the membrane fraction can occur without translocation, and these data would also be consistent with increased protein synthesis of PKC- $\theta$ and PKC- $\varepsilon$ in the fed state.

PKC- $\theta$ is the major isoenzyme of PKC in muscle (Osada et al. 1992); we have previously shown that expression of PKC- $\theta$ varies between muscles of different fibre-type composition and insulin sensitivity, and that expression of this isoform is increased in muscle tissue from rats with fructose-induced insulin resistance and dyslipidaemia (Donnelly et al. 1994). It has recently been shown that PKC- $\theta$ has an especially strong inhibitory effect on insulin receptor signalling which involves phosphorylation of IRS-1 (Kellerer et al. 1998). Increased expression of PKC- $\varepsilon$ and PKC $-\theta$ in muscle has also been reported in the high-fat-fed rat (Schmitz-Peiffer et al. 1997), which is another (nonobese) dietary model of insulin resistance associated with increased lipid levels in muscle tissue which parallel the decline in whole-body insulin sensitivity (Storlien et al. 1991). The work by Schmitz-Pfeiffer et al. (1997) showed evidence of chronic activation of PKC- $\varepsilon$ in high-fat-fed Wistar rats, whereas their data for PKC $-\theta$ suggested a combination of chronic activation and down-regulation because PKC- $\theta$ expression was reduced in the cytosol fraction. The present study reports slightly different changes in muscle PKC in response to acute feeding under conditions of a normal dietary intake, whereas Schmitz-Peiffer et al. (1997) were concerned with chronic feeding of an experimental high-fat diet.

The significance of increased expression of PKC- $\varepsilon$ in obese compared with lean animals in the present study may be relevant to the role of tumour necrosis factor $\alpha$ $(\mathrm{TNF} \alpha)$ in obesity. Secretion of TNF $\alpha$ from adipocytes of obese rats inhibits glucose uptake in skeletal muscle (Hotamisligil et al. 1993) and there is evidence that PKC- $\varepsilon$ enhances the inhibitory effect of TNF $\alpha$ on insulin signalling (Kellerer et al. 1997). Thus, enhanced DAG-mediated activation of PKC- $\theta$ and $\mathrm{PKC}-\varepsilon$ in the muscles of obese Zucker rats under postprandial conditions may, via several mechanisms, down-regulate insulin signalling and glucose disposal and worsen the hyperglycaemia observed in these animals.

The notion that DAG-mediated PKC activation contributes to the pathogenesis of obesity-induced insulin 
Table 2 PKC activity (pmol/min/mg protein) in cytosol and membrane (particulate) fractions of three insulin target tissues from obese $f a / f a$ and lean $f a /-$ Zucker rats under fed and overnight-fasted conditions. Values are means \pm S.E.M.

\begin{tabular}{|c|c|c|c|c|c|}
\hline & \multirow[b]{2}{*}{ Animal } & \multicolumn{2}{|c|}{ Fasted $(n=12)$} & \multicolumn{2}{|c|}{ Fed $(n=12)$} \\
\hline & & Cytosol & Membrane & Cytosol & Membrane \\
\hline $\begin{array}{l}\text { Tissue } \\
\text { Soleus muscle }\end{array}$ & $\begin{array}{l}\text { Obese } \\
\text { Lean }\end{array}$ & $\begin{array}{l}49 \pm 9 \\
47 \pm 6\end{array}$ & $\begin{array}{l}107 \pm 20 \\
154 \pm 21\end{array}$ & $\begin{array}{l}46 \pm 13 \\
57 \pm 16\end{array}$ & $\begin{array}{l}283 \pm 42^{*} \dagger \\
179 \pm 27\end{array}$ \\
\hline Liver & $\begin{array}{l}\text { Obese } \\
\text { Lean }\end{array}$ & $\begin{array}{l}37 \pm 5 \\
28 \pm 3\end{array}$ & $\begin{array}{l}174 \pm 16^{*} \\
108 \pm 12\end{array}$ & $\begin{array}{l}47 \pm 4 \\
50 \pm 5\end{array}$ & $\begin{array}{l}186 \pm 22 \\
127 \pm 16\end{array}$ \\
\hline Epididymal fat & $\begin{array}{l}\text { Obese } \\
\text { Lean }\end{array}$ & $\begin{array}{l}47 \pm 11 \\
42 \pm 9\end{array}$ & $\begin{array}{l}199 \pm 48 \\
173 \pm 45\end{array}$ & $\begin{array}{l}99 \pm 26 \\
92 \pm 15\end{array}$ & $\begin{array}{l}255 \pm 42 \\
234 \pm 35\end{array}$ \\
\hline
\end{tabular}

${ }^{*} P<0.05$ compared with corresponding value for lean rats; $\uparrow P<0.02$ vs membrane of soleus muscle from fasted rats.

resistance provides an attractive mechanism linking dysregulated lipid metabolism with resistance to insulinmediated glucose utilisation, especially in muscle (Cortright et al. 1997). Accumulation of naturally occurring lipid metabolites, e.g. unesterified free fatty acids and their coenzyme A esters, activates PKC synergistically with DAG (Shimomura et al. 1991). The substrates phophorylated at serine and threonine residues in response to PKC activation have largely been identified in vitro, but there is evidence that the insulin receptor tyrosine kinase on the $\beta$-subunit is an important target (Karisik et al. 1990, Kellerer et al. 1997), as well as phosphorylation
A

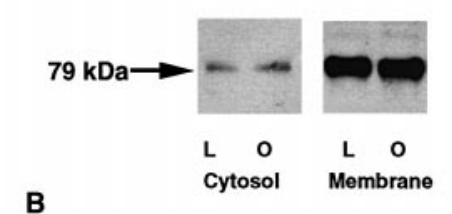

B

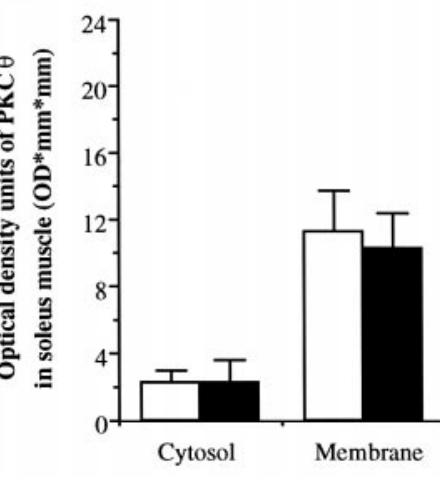

Fasted
Fed

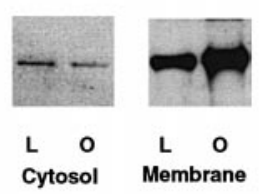

A

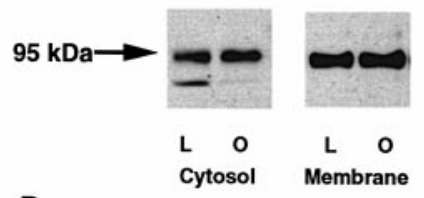

of IRS-1 (De Fea \& Roth 1997) and inhibition of insulin-stimulated Akt1 and Akt3 activity (Barthel et al. 1998). Several previous studies have demonstrated impaired tyrosine kinase activity in the Zucker fatty rat insulin receptor (Slieker et al. 1990), but whether PKC activation accounts for this reduction in the tyrosine kinase activity in vivo requires further investigation (Bassenmaier et al. 1997).

Because the majority of whole-body glucose disposal in the fed state is accounted for by skeletal muscle (approximately 85\%), PKC-mediated phosphorylation and down-regulation of glycogen synthase (Blackmore et al.

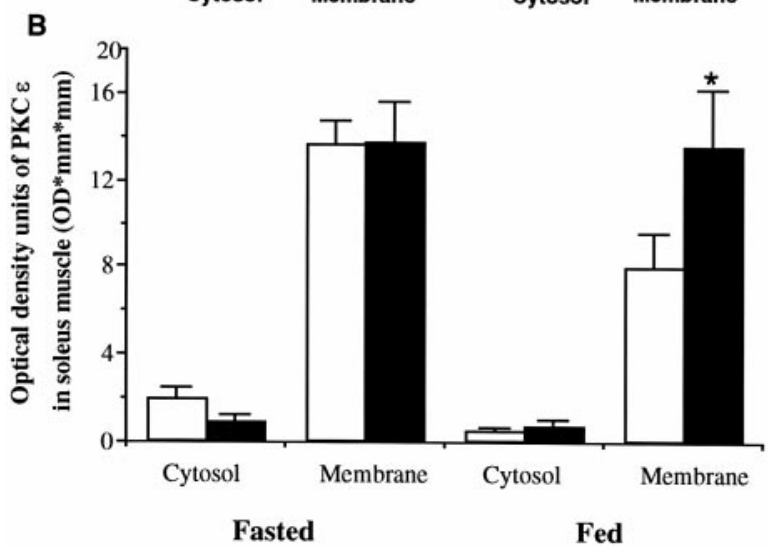

Figure 3 Western blots of PKC- $\varepsilon(95 \mathrm{kDa})$ in cystosol and membrane fractions of soleus muscle from obese $(\mathrm{O})$ and lean $(\mathrm{L})$ Zucker rats under fed and fasting conditions. Typical blots (A) and summary of densitometric data (B): lean (open bars, $n=12$ ) and obese (solid bars, $n=12$ ) groups are shown. ${ }^{*}, P<0 \cdot 01$ vs lean. 
Table 3 Comparison of densitometric data for two nPKC isoforms, PKC $-\theta$ and PKC- $\varepsilon$, from Western blots of cytosol and membrane fractions of soleus muscle from obese $\mathrm{fa} / \mathrm{fa}$ rats relative to lean $\mathrm{fa} /$ - controls. Data are means \pm S.E.M. The ratio is calculated using the lean sample as control for each obese sample. The samples were analysed in parallel and subjected to SDS-PAGE on the same gel

\begin{tabular}{|c|c|c|c|}
\hline & & Fasted $(n=12)$ & Fed $(n=12)$ \\
\hline & Fraction & Obese/lean ratio & Obese/lean ratio \\
\hline \multicolumn{4}{|l|}{ Isoform } \\
\hline \multirow[t]{2}{*}{ PKC- $\theta$} & Cytosol & $1 \cdot 01 \pm 0 \cdot 18$ & $1 \cdot 55 \pm 0 \cdot 39$ \\
\hline & Membrane & $1 \cdot 03 \pm 0 \cdot 18$ & $1 \cdot 45 \pm 0 \cdot 17^{*}$ \\
\hline \multirow[t]{2}{*}{ PKC- $\varepsilon$} & Cytosol & $0.89 \pm 0.57$ & $1 \cdot 54 \pm 0 \cdot 61^{*}$ \\
\hline & Membrane & $1 \cdot 02 \pm 0 \cdot 10$ & $2 \cdot 64 \pm 0.69^{\star *}$ \\
\hline
\end{tabular}

${ }^{*} P<0 \cdot 05,{ }^{* *} P<0 \cdot 01$ compared with corresponding data in the fasted state.

Table 4 DAG levels (nmol/mg protein) in cytosol and membrane fractions of soleus muscle tissue from obese $\mathrm{fa} / \mathrm{fa}$ and lean $\mathrm{fa} /$ - Zucker rats under fed and fasted conditions. Values are means \pm S.E.M.

\begin{tabular}{|c|c|c|c|c|}
\hline & \multicolumn{2}{|c|}{ Fasted rats $(n=12)$} & \multicolumn{2}{|c|}{ Fed rats $(n=12)$} \\
\hline & Cytosol & Membrane & Cytosol & Membrane \\
\hline Obese $f a / f a$ & $2 \cdot 30 \pm 0 \cdot 20^{*}$ & $10 \cdot 54 \pm 1.55$ & $1.98 \pm 0.07$ & $12 \cdot 55 \pm 1 \cdot 33^{*}$ \\
\hline Lean $\mathrm{fa} /-$ & $1 \cdot 42 \pm 0 \cdot 12$ & $9 \cdot 07 \pm 0 \cdot 48$ & $1 \cdot 95 \pm 0 \cdot 23$ & $9 \cdot 06 \pm 0 \cdot 60$ \\
\hline
\end{tabular}

1986) may also be an important consequence of the PKC activation observed in muscles of obese rats under fed conditions. In addition, local formation of nitric oxide (NO) stimulates glucose uptake in isolated rat skeletal muscles and there is evidence that NO-mediated glucose oxidation is reduced in muscles from obese Zucker rats (Young \& Leighton 1998). Given that PKC activation regulates the activity of nitric oxide synthase (Huang \& Yuan 1997), it is also possible that local differences in NO formation contribute to $\mathrm{PKC}-$ mediated insulin resistance in skeletal muscle.

In conclusion, the obese Zucker rat is associated with tissue and isoform-specific upregulation of DAG-PKC signalling, which is related to food intake, and there is increasing evidence that these biochemical changes contribute to the insulin resistance and metabolic abnormalities associated with obesity and diabetes.

\section{Acknowledgements}

This work was supported by a project grant from the National Health \& Medical Research Council of Australia.

\section{References}

Anai K, Funaki M, Ogihara T, Terasaki J, Inukai K, Ketagiri $\mathrm{H}$, Fukushima Y, Yazaki Y, Kikuchi M, Oka Y \& Asano T 1998
Altered expression levels and impaired steps in the pathway to phosphoinositol 3-kinase activation via insulin receptor substrates 1 and 2 in Zucker fatty rats. Diabetes 47 13-23.

Avignon A, Yamada K, Zhou X, Spencer B, Cardona O, Saba-Siddique S, Galloway L, Standaer TML, \& Farese RV 1996 Chronic activation of protein kinase $\mathrm{C}$ in soleus muscles and other tissues of insulin-resistant Type II diabetic Goto-Kakizaki (GK), obese/aged and obese/zucker rats. Diabetes 45 1396-1404.

Azhar S $1991 \mathrm{Ca}^{2+}$-activated and phospholipid-dependent hepatic protein kinase (protein kinase $\mathrm{C}$ ): a standardised method for the determination of enzyme activity. Journal of Nutritional Biochemistry 2 165-171.

Barthel A, Nakatani K, Dandekar AA \& Roth RA 1998 Protein kinase $\mathrm{C}$ modulates the insulin-stimulated increase in Akt1 and Akt3 activity in 3T3-L1 adipocytes. Biochemical and Biophysical Research Communications 243 509-513.

Bassenmaier B, Mosthaf L, Mischak H, Ullrich A \& Haring HU 1997 Protein kinase $\mathrm{C}$ isoforms beta- 1 and beta- 2 inhibit the tyrosine kinase activity of the insulin receptor. Diabetologia 40 863-866.

Berti L, Mosthaf L, Kroder G, Kellerer M, Tippmer S, Mushack J, Seffer E, Seedorf K \& Haring HU 1994 Glucose-induced translocation of protein kinase $\mathrm{C}$ isoforms in rat-1 fibroblasts is paralleled by inhibition of the insulin receptor tyrosine kinase. Journal of Biological Chemistry 269 3381-3386.

Blackmore PF, Strickland WG, Bocckino SB \& Exton JH 1986 Phosphorylation of glycogen synthase by protein kinase C. Biochemical Journal 237 235-242.

Bligh EG \& Dyer WJ 1959 A rapid method of total lipid extraction and purification. Canadian Journal of Biochemistry and Physiology 37 911-917.

Boneh A 1995 Possible role of protein kinase C in the pathogenesis of inborn errors of metabolism. Journal of Cellular Biochemistry $\mathbf{5 9}$ $27-32$. 
Bradford MM 1976 A rapid and sensitive method for the quantitation of microgram quantities of protein utilising the principle of protein-dye binding. Analytical Biochemistry 72 248-254.

Busch AK, Castan I, Degerman E, Tornqvist H \& Mosthaf L 1998 Protein kinase C mediates hyperglycaemia-induced insulin resistance through serine phosphorylation of IRS-1. Diabetologia 41 (Suppl 1) A10.

Caro JF, Jenquin M \& Long S 1992 Effects of phorbol esters on insulin receptor function and insulin action in hepatocytes: evidence for heterogeneity. Molecular and Cellular Biochemistry 109 115-118.

Chin JE, Dickens M, Tavare JM \& Roth RA 1993 Overexpression of protein kinase $\mathrm{C}$ isozymes $\alpha, \beta \mathrm{I}, \gamma$, and $\varepsilon$ in cells overexpressing the insulin receptor. Journal of Biological Chemistry 268 6338-6347.

Chua SC, Chung WK, Wu-Peng XS, Zhang Y, Liu S-M, Tartaglia L \& Leibel RL 1996 Phenotypes of mouse diabetes and rat fatty due to mutations in the OB (leptin) receptor. Diabetes 45 1141-1143.

Considine RV \& Caro JF 1993 Protein kinase C: mediator or inhibitor of insulin action? Journal of Cellular Biochemistry 52 8-13.

Considine RV, Nyce MR, Allen LE, Morales LM, Triester S, Serrano J, Colberg J, Lanza-Jacoby S \& Caro JF 1995 Protein kinase C is increased in the liver of humans and rats with non-insulindependent diabetes mellitus: an alteration not due to hyperglycaemia. Journal of Clinical Investigation 95 2938-2944.

Cortright RN, Muoio DM \& Dohm GL 1997 Skeletal muscle lipid metabolism: a frontier for new insights into fuel homoestasis. Journal of Nutritional Biochemistry 8 228-245.

De Fea K \& Roth RA 1997 Protein kinase C modulation of insulin receptor substrate-1 tyrosine phosphorylation requires serine $6_{1 \mathrm{Z}}$. Biochemistry 36 12939-12947.

Donnelly R, Reed M, Azhar S \& Reaven GM 1994 Expression of the major isoenzyme of protein kinase C in skeletal muscle, nPKC- $\theta$, varies with fibre-type composition and in response to fructoseinduced insulin resistance. Endocrinology 135 2369-2374.

Ferrannini E, Natali A, Bell P, Carallo-Perin P, Lalic N \& Mingrone G 1997 Insulin resistance and hypersecretion in obesity. Journal of Clinical Investigation 100 1166-1173.

Heydrick SJ, Ruderman NB, Kurowski TG, Adams HB \& Chen KS 1991 Enhanced stimulation of diacylglycerol and lipid synthesis by insulin in denervated muscle. Altered PKC activity and possible link to insulin resistance. Diabetes 40 1707-1711.

Hotamisligil GS, Shargill NS \& Spiegelman BM 1993 Adipose expression of tumour necrosis factor- $\alpha$ : direct role in obesity-linked insulin resistance. Science 259 87-91.

Huang Q \& Yuan Y 1997 Interaction of PKC and NOS in signal transduction of microvascular permeability. American Journal of Physiology 273 H2442-H2451.

Hug H \& Sarre TF 1993 Protein kinase C isoenzymes: divergence in signal transduction. Biochemical Journal 291 329-343.

Ishizuka T, Yamamoto M, Kajita K, Yasuda K, Miura K, Hernandez H \& Farese RV 1993 Differential effect of aging on protein kinase $\mathrm{C}$ activity in rat adipocytes and soleus muscle. Metabolism $\mathbf{4 2}$ 420-425.

Karisik A, Rothenberg PL, Yamada K, White MF \& Kahn CR 1990 Increased protein kinase $\mathrm{C}$ activity is linked to reduced insulin receptor autophosphorylation in liver of starved rats. Journal of Biological Chemistry 265 10226-10231.

Kellerer M, Mushack J, Mischak H \& Haring HU 1997 Protein kinase $\mathrm{C}$ (PKC) epsilon enhances the inhibitory effect of TNF $\alpha$ on insulin signalling in HEK293 cells. FEBS Letters 418 119-122.
Kellerer M, Mushack J, Seffer E, Mischak H, Ullrich A \& Haring HU 1998 Protein kinase $C$ isoforms $\alpha, \delta$ and $\theta$ require insulin receptor substrate- 1 to inhibit the tyrosine kinase activity of the insulin receptor in human kidney embryonic cells (HEK 293 cells). Diabetologia 41 833-838.

King PA, Horton ED, Hirshman MF \& Horton ES 1992 Insulin resistance in obese Zucker rat $(f a / f a)$ skeletal muscle is associated with a failure of glucose transporter translocation. Journal of Clinical Investigation 90 1568-1575.

Laemmli UK 1970 Cleavage of structural proteins during the assembly of the head of bacteriophage T4. Nature 227 680-685.

Mosthaf L, Busch AK, Juhl LF, Nielsen L, Olsen GS, Ikeda Y \& Seedorf K 1998 The insulin receptor is degraded by specific protein kinase C isoforms. Diabetologia 41 (Suppl 1) A10.

Moule SK \& Denton RM 1997 Multiple signaling pathways involved in the metabolic effects of insulin. American Journal of Cardiology $\mathbf{8 0}$ 41A-49A.

Osada S-I, Mizuno K, Saido TC, Suzuki K, Kuroki T \& Ohno S 1992 A new member of the protein kinase C family, nPKC- $\theta$, predominantly expressed in skeletal muscle. Molecular and Cellular Biology 12 3930-3938.

Pan DA, Lillioja S, Kriketos AD, Milner MR, Bauer LA, Bogardus C, Jenkins AB \& Storlien LH 1997 Skeletal muscle triglyceride levels are inversely related to insulin action. Diabetes $\mathbf{4 6}$ 983-988.

Preiss JE, Loomis CR, Bell RM \& Niedel JE 1987 Quantitative measurement of sך-1, 2-diacylglycerols. In Methods in Enzymology, Part B Calcium and Lipids, pp 294-300. Eds PM Conn \& AR Means. Orlando, Florida: Academic Press Inc.

Schmitz-Peiffer C, Browne CL, Oakes ND, Watkinson A, Chisholm DJ, Kraegen EW \& Biden TJ 1997 Alterations in the expression and cellular localization of protein kinase $\mathrm{C}$ isozymes epsilon and theta are associated with insulin resistance in skeletal muscle of the high-fat-fed rat. Diabetes 46 169-178.

Shimomura T, Asoka Y, Oka M, Yoshida K \& Nishizuka Y 1991 Synergistic action of diacylglycerol and unsaturated fatty acid for PKC activation: its possible implication. Proceedings of the National Academy of Sciences of the USA 88 5149-5153.

Shmueli E, Alberti KGEM \& Record CO 1993 Diacylglycerol/ protein kinase $\mathrm{C}$ signalling: a mechanism for insulin resistance? Journal of Internal Medicine 234 397-400.

Slieker LJ, Roberts EF, Shaw WN \& Johnson WT 1990 Effect of streptozotocin-induced diabetes on insulin receptor tyrosine kinase activity in obese Zucker rats. Diabetes 39 619-625.

Storlien LH, Jenkins AB, Chisholm DJ, Pascoe WS, Khouri S \& Kraegen EW 1991 Influence of dietary fat composition on development of insulin resistance in rats. Relationship to muscle triglyceride and W-3 fatty acids in muscle phospholipids. Diabetes 40 280-289.

Young ME \& Leighton B 1998 Evidence for altered sensitivity of the nitric oxide/cGMP signalling cascade in insulin-resistant skeletal muscle. Biochemical Journal 329 73-79.

Received 2 December 1998

Revised manuscript received 10 February 1999

Accepted 1 March 1999 